\title{
Assessment of Business Process Alignment to IT Business Objectives
}

\author{
Vincentius Octavianus ${ }^{1}$, Harryston Nagata ${ }^{2}$, Johanes Fernandes Andry ${ }^{3}$ \\ 1,2,3 Information System Department, Universitas Bunda Mulia, Jakarta \\ e-mail: ${ }^{1}$ vincentius.demus@gmail.com, ${ }^{2}$ harrystonnagata08@gmail.com, \\ 3jandry@bundamulia.ac.id
}

\begin{abstract}
Manufacturing company is a company engaged in the manufacture of household appliances such as plastic houseware, bushels food, rice bucket, and so forth. the company has implemented an application in running the business process of goods sales and goods (inventory). However, there is a problem in the application that is used to support the activity in the business process that is the discrepancy with the needs of users of the application and will be an assessment of the business process. Therefore, the authors take this topic. The purpose of this study is to determine the deficiencies that occur in the company, so the author can provide recommendations to the company about what should be improved. The research method used in this research is qualitative research and data obtained from the interview. In this study, the assessment of the business process Manufacturing company using COBIT 4.1 and Balanced Scorecard (BSC). This research focuses on PO3 (Determine Technological Direction) domains, PO4 (Communications Management Aims and Direction), PO8 (Manage Quality), and AI4 (Enable Operation and Use). From the research that has been done, the results show that this company has not reached the expected maturity level.
\end{abstract}

Keywords - Assessment, business process, IT business objective, COBIT, Balanced Scorecard

\section{INTRODUCTION}

In a world with the emergence of technological advancement, penetration of information technology into the organizations is more increasing. Adoption of information technology in core organizational processes is becoming inseparable intertwined in performing everyday activities [1]. In this era of competition and globalization information systems and information technology has an important contribution for the organization to meet its objectives and become the leader of its competitors [2]. Fadzil et al (2005) says, the technological revolution in auditing began in 1954 with the first computer business operations [3,4,5]. Today, most management considers the need for IT as an "organizational strategic player". As organizational strategies change over time, IT must change as well [6]. Many organizations make large investments in IT to secure or sustain a competitive advantage [7]. Information technology has supported all sectors. With the information technology, target achievement can be more easily and more maximized because information technology can simplify and maximize it directly and also indirectly [8]. If there is a problem in information technology, then the problem must be immediately found and given a solution, so that information technology in a company can run according to the needs of the company, of course, problems with information technology can be audited.

Audit information system required a standard. The standard used in this research is COBIT. Control Objectives for Information and Related Technology (COBIT) is a standard in IT governance to assist a company in controlling business needs within the enterprise, where business needs include IT activities and emphasize activities to be achieved and controlled effectively $[9,10]$. In addition to conducting an audit information system, the authors also conduct a company performance assessment with BSC. The BSC seems to offer great potential 
to local authorities in terms of contributing both to increased performance and to increased performance measurement $[11,12]$. BSC is a system that enables organizations to translate vision and strategy into action and BSC is a tool to formalize what the organization should measure [13]. At first the BSC focused on business strategy, but it could also be applied to processes occurring within the company, including innovation [14]. In this study, the author conducted a research on a manufacturing company.

A company engaged in the manufacture of household appliances, plastic houseware, bushels food, rice bucket, and others. In managing the sales and receipt process of goods, the company uses a self-developed application, where the implementation of the application has not been audited at all. The company's problems lie in its business processes, where applications have not fully supported the company's business processes. To ensure alignment with IT business objectives, an audit of information systems is required.

According to these problems, the author wants to audit information system using COBIT 4.1 with PO and AI domains, where PO domain identifies how IT can contribute to the organization in achieving the organization's business goals, how to form a good organization with technology infrastructure and AI domain identifies IT solutions and implements and integrates them into business processes to realize IT strategy [15]. COBIT 4.1 and BSC standards are used with the aim that the future of business processes in manufacturing company is getting better.

From an earlier study, the first author is Michele Rubino and Fillippo Vitolla (2014) in a journal entitled "Internal control over financial reporting: the opportunities using the COBIT framework", describes analysis showing that the application of the COBIT framework, or more commonly implementation of effective IT controls, providing important benefits to the entire company or organization. IT control objectives have a direct impact on IT control weaknesses and indirectly in other categories of material weakness [16].

The second author is Fahmi Fadhl Al-Hosaini and Saudah Sofian (2015) in a journal entitled "A Review of the Balanced Scorecard Framework in Higher Education Institutions (HEIs)", describes that the Balanced Scorecard is presented as a tool that can be used to strategize and monitor organizational performance, continue to benchmark this with key elements of the strategic plan [17].

\section{RESEARCH METHODOLOGY}

In this research there are 3 stages, that is:

2.1. Research

The process starts from the literature review. Literature review is stage where the author describes the theories are used in this study, those theories are COBIT, Balanced Scorecard, PO and AI domains, and Business Process. Furthermore, the next process is the initial survey. Initial survey is the stage where the author conducted a survey at the beginning of research conducted by coming to the company that serve as the object of this study. After the initial survey, the next stage is taking survey data where the authors obtain data survey results that have been done previously in the company that serve as the object in this study. After the literature review, initial survey, and taking survey data conducted, then the final process in this stage is to draw conclusions from all that has been done.

2.2. Interview

The process starts from design interview questions. Design interview questions is the process by which the author designs the questions that will be interviewed to the company. Then the next process is a question analysis, in this process the authors analyze the questions that have been made / designed, if the questions are not enough or there are still questions that are not true, it will be re-designing on these questions. If the questions are correct and sufficient, then the next step is taking survey data. Taking a survey of data here is to interview the company and by conducting an interview, the authors will get the results of the interviews that 
have been done. With the data obtained from the results of interviews, then the next author to analyze the results of interviews. Then the final process is to draw conclusions from what has been obtained.

\subsection{Questionnaire}

The process starts from designing the questionnaire questions. in this process, the authors make the questions put into the questionnaire. Furthermore, the authors analyze the questions, if there are still questions that are not true or something is missing, then back to the previous process where the authors make improvements by redesigning these questions. If the questions are correct and sufficient, then the next process is taking questionnaire data, where the data obtained from the questionnaire that has been filled by the company. After obtaining the results of the questionnaire, then analyzed the results obtained from the questionnaire. If the author has finished the analysis, then the last process is to draw conclusions from all that has been obtained.

Figure 1 shows the flow of stages and processes in the research methodology.

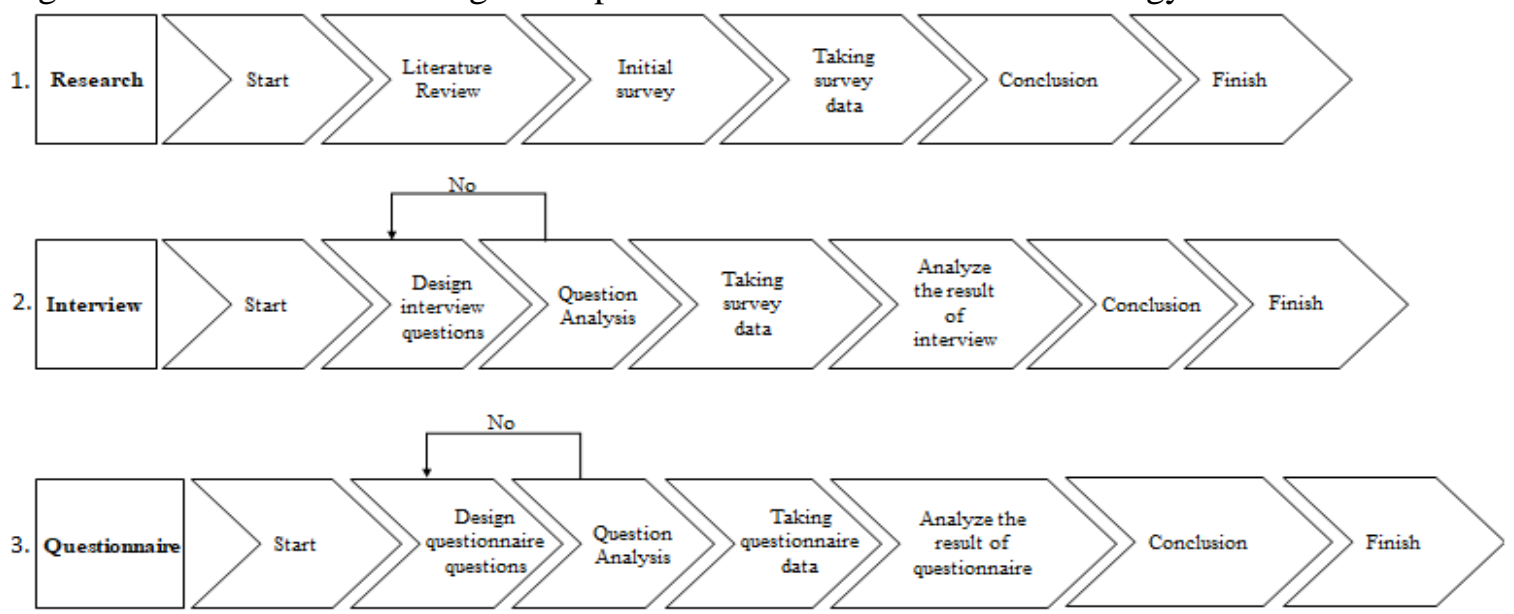

Figure 1. Research Design [18]

\section{RESULTS AND DISCUSSION}

The results of this study were obtained from the measurement of the maturity level of the manufacturing company by observing the company and interviewing the employees working in the IT division who handled the sales and inventory applications. Interviews are made to 2 peoples that knowing the details of the application and are responsible for the application, namely IT staff and company directors by visiting the company and providing a number of questions that have been made based on sub domains on COBIT 4.1. At this stage the author will discuss about the results of analysis and discussion related to the results of the analysis. The analysis of the study was based on a methodology already described. In this study, the authors did the analysis with sub domains of PO3 (Determine Technological Direction), PO4 (Define the IT Processes, Organisation and Relationships), PO6 (Communicate Management Aims and Direction), PO8 (Manage Quality), and AI4 (Enable Operation and Use). The authors will see the extent of achieving the level of maturity. With the desired maturity level is 3 , the authors will give recommendation to the company. In addition to using a domain based on COBIT 4.1, in this study also uses the balanced scorecard framework. From 4 perspective balanced scorecard, the author uses one of them is internal perspective, where according to Gekonge (2005) as quoted by Kairu et al (2013), internal processes perspective focuses on the internal 
business results that aim to financial success and satisfied customers [19,20,21]. The perspective is linked to domains based on COBIT 4.1.

\subsection{Plan and Organize (PO)}

This domain includes strategies and tactics and involves identifying how IT can best contribute to the achievement of business objectives. The realization of strategic vision needs to be planned, communicated and managed for different perspectives. The right organization and technology infrastructure should be prepared. For the PO domain, the authors use PO3, PO4, PO6 and PO8. The purpose of PO3 is to determine techonology direction that satisfies the business requirement for IT of stability, cost effectively, standard and integrated application system, resources and capabilities that fulfill current and future business requirements and focus on defining and implementing a technology infrastructure plan, architecture and standards that recognise and leverage technology opportunities.

The purpose of PO4 is to define the IT processes, organization and relationships and focus on effective and efficient IT investment and portfolio decisions, and by setting and tracking IT budgets in line with IT strategy and investment decisions. The purpose of PO6 is to communicate management aims and direction that satisfies the business requirement for IT of provide accurate and timely information on current and future IT service and related risks and responsibilities, focus on providing accurate, understandable and approved policies, procedures, guidelines and other documentation to stakeholders, embedded in an IT control framework. The purpose of PO8 is to manage quality that satisfies the business requirement for IT of assure continuous and measurable improvement of IT services delivered and focus on the definition of a QMS, ongoing performance monitoring against predefined objectives and implementation of a programme for continuous improvement of IT services. Table 1 is the result of the maturity level of the assessment calculation using PO domain.

Table 1. Average Maturity Level of PO domain

\begin{tabular}{|c|c|c|c|}
\hline $\begin{array}{c}\text { Sub } \\
\text { Domain }\end{array}$ & $\begin{array}{c}\text { Control } \\
\text { Objective }\end{array}$ & $\begin{array}{c}\text { Current } \\
\text { Level }\end{array}$ & $\begin{array}{c}\text { Expected } \\
\text { Level }\end{array}$ \\
\hline PO3 & Determine Technological Direction & 1.33 & 3 \\
\hline PO4 & Define the IT Processes, Organisation and Relationships & 1.3 & 3 \\
\hline PO6 & Communicate Management Aims and Direction & 1 & 3 \\
\hline PO8 & Manage Quality & 1.2 & 3 \\
\hline
\end{tabular}

For the PO3 domain has not reached the expected level and the gap between the current maturity level and the expected maturity level because the result of interview on PO3 is in the company has not been focused approach to infrastructure planning and infrastructure development both in terms of engineering, and infrastructure development itself. So, the company is only limited to making its own application and use it, but there is no further planning and development of IT infrastructure. But besides that, the company already know the importance of technology infrastructure planning, also IT personnel in the company already have knowledge and expertise in the development of IT infrastructure. In addition, the company in the future will develop sophisticated technology infrastructure and responsive to technological change if it is really necessary. The recommendation that the company should have a plan that is focused on technical solutions in technical problems, not to meet business needs. In addition, the company is also recommended for the existence of techniques and standards for developing infrastructure components. Then, the process of developing sophisticated technology infrastructure planning and responsive to change must be continuous so that the infrastructure in the company can grow, not only if it is needed.

For the PO4 domain also has not reached the expected level and the gap between the current maturity level and the expected maturity level because the result of interview on PO4 is the company has not set IT organizational structure that reflects the needs of both internal and 
external business, then the company also has no process for regular review of IT organizations because the company is not moving in the IT field, in this manufacturing company nor have there been any oversight in the IT function that ensures that the roles and responsibilities of the personnel are carried out properly. In addition, the company also has not put IT function into the overall organizational structure, but the company has been thinking about it quietly, but now most of the work process in the company is still done manually. The company also still lacks employees so some divisions sometimes help each other division work. In addition, IT governance can be ensured as part of corporate governance, but is limited to network and application troubleshooting, and there is also responsibility for information security and physical security as there are IT personnel assigned to network security and there are also security guards keeping for 24 hours. The recommendation that the company should put the IT function on the overall organizational structure. In addition, the company is also recommended to conduct periodic review of IT so that the company can adjust and meet the expected business objectives and the implementation of adequate supervision in the IT function to ensure the roles and responsibilities have been implemented correctly.

For the PO6 domain also has not reached the expected level and the gap between the current maturity level and the expected maturity level because the result of interview on PO6 is there are no control in an IT environment that is aligned with company management, the development and maintenance of policies in support of IT strategy is not yet available, and there is no enforcement of IT policy for all staff. But in addition, in this company there is continuous improvement in case of errors or incompatibilities on the needs of users, then, in this company there is also a good handling of the process irregularities. The company also communicates the understanding of purpose and directs as the system is needed to support the work. The recommendation is that companies must exercise control in an IT environment that aligns with company management, develops and maintains policies to support IT strategy. In addition, the company is also recommended for reference to procedures, standards and guidelines for IT policy and enforce IT policy for all staff

For the PO8 domain has not reached the expected level and the gap between the current maturity level and the expected maturity level because the result of interview on PO8 is the lack of scalability in the development and validation of the requirements, the system test plan, and testing the system itself, there is currently no planning and implementation of measurements to monitor the quality management system. There is also no measurement, monitoring and recording of information used by app users to make correct corrections and precautions when it comes to in-app issues because fixes will be made instantly when they get reports of problems from users of those apps, and companies have not set language standards programming and file formats in software development, as well as the absence of regular maintenance of the overall quality of the system, but perhaps the future will be like that. In addition, the company identifies and maintains the standards, procedures, and practices of IT processes in meeting the quality management system, the company also adopts and maintains quality standards in the system development of the parent company. The recommendation of the authors is that the company must create scalability for development and testing and validation of requirements, test plans, and system testing, then the company must also maintain the overall quality of the system on a regular basis. In addition, the company is also recommended to conduct measurement planning and implementation to monitor the quality management system, and make measurements, monitoring and recording of information used by the user to perform appropriate repairs and prevention.

\subsection{Acquire and Implementation (AI)}

This domain is to realize IT strategy, indentify IT solution needs, developed or acquired, and implemented and integrated into business processes. In addition, changes and maintenance of existing systems are included in this domain to ensure solutions continue to meet business objectives. For the AI domain, the authors use AI4 domain. 
The purpose of AI4 domain is enable operation and use, that satisfies the business requirement for IT of ensuring satisfaction of end users with service offerings and service levels and seamlessly integrating applications and technology solutions into business processes and this domain focus on providing effective user and operational manuals and training materials to transfer the knowledge necessary for successful system operation and use. This domain is achieved by developing and making available knowledge transfer documentation, communicating and training users, business management, support staff and operational staff, and producing training materials. Table 2 is the result of the maturity level of the assessment calculation using AI domain.

Table 2. Average Maturity Level of AI domain

\begin{tabular}{|c|c|c|c|}
\hline Sub Domain & $\begin{array}{c}\text { Control } \\
\text { Objective }\end{array}$ & Current Level & Expected Level \\
\hline AI4 & Enable Operation and Use & 1 & 2 \\
\hline
\end{tabular}

For the AI4 domain has not reached the expected level because the result of interview on AI4 is there are no plan to identify all aspects, either from the aspect of the system, the operational aspects of the system, to the aspects of system usage. In the company there is also no transfer of knowledge about IT to business management that enables one to take over systems and data, and there is also no explanation of IT expertise that enables technical support staff to maintain systems and infrastructure effectively and efficiently.

In addition, there is a responsibility for service delivery and supervision of system quality and internal control, and there is also an explanation of the explanation of IT knowledge that enables a user to use the system effectively and efficiently to support business processes. The recommendation from the authors is that the company should develop plans to identify all technical aspects of the system, system operational aspects, and aspects of system usage. In addition, the company is also recommended to conduct training on IT expertise to technical support staff, so that enables technical support staff to maintain systems and infrastructure effectively and efficiently.

In figure 2 can be seen the gap between the current maturity level with expected maturity level, where the average value still at maturity level 1, while the expected level is on level 3.

Figure 2 shows the gap between the average current maturity level of all sub domains PO3, PO4, PO6, PO8, and AI4. Where it can be seen that the average current maturity level at PO3 is 1.33 while the expected maturity level is 3 , the average current maturity level at PO4 is 1.3 whereas the expected maturity level is 3, the average current maturity level at PO6 is 1 whereas the expected the maturity level is 3 , the average current maturity level at PO8 is 1.2 whereas the expected maturity level is 3 , and so is the AI4, where the average of current maturity level is 1 whereas the expected maturity level is 2 . 


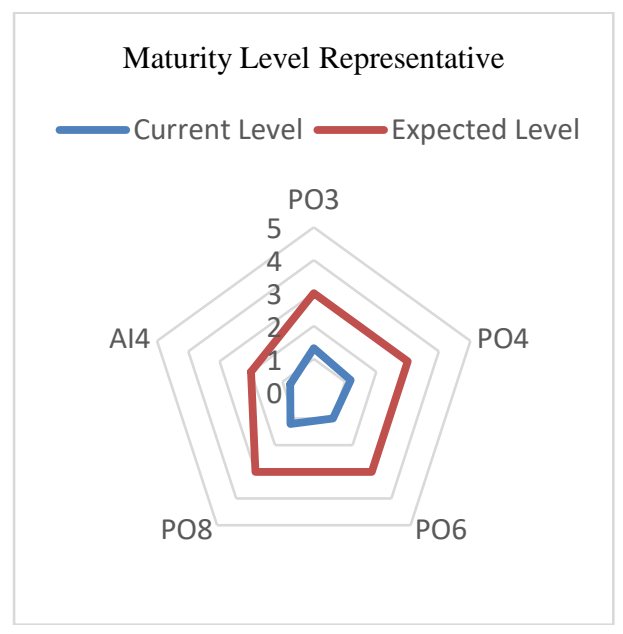

Figure 2. Maturity Level Representative

Next, the authors the author connects between IT goals and IT processes. In Table 3 can be seen the mapping IT goals to COBIT's IT processes and the information criteria on which the IT goal is based, in which there are IT goals, processes taken from the COBIT domain used in this study, and the COBIT information criteria consisting of effectiveness, efficiency, confidentiality, integrity, availability, compliance, and reliability obtained from sub domains in COBIT 4.1, where in the COBIT information criteria there are the letters ' $\mathrm{P}$ ' means 'Primary' and 'S' meaning 'Secondary'. Later on, business goals will be linked to these IT goals that are also linked into an internal balanced scorecard perspective, and discussion of internal perspectives associated with business goals and IT goals will be discussed in the next table. The first IT goals (Respond to business requirements in alignment with the business strategy) are linked to the process of PO4 (Define the IT Processes, Organization and Relationships), and on the COBIT information criteria there is a primary in effectiveness and efficiency.

The second IT objective (Respond to governance requirement in line with board direction) is linked to the PO4 process as well and on the COBIT information criteria there is a primary on effectiveness and efficiency. The third IT objective (Create IT agility) is associated with the process of PO4 (Define the IT Processes, Organization and Relationships), and on the COBIT information criteria there is a primary in effectiveness and efficiency. The fourth IT goals (Acquire and maintain integrated and standardized application systems) are linked to the PO3 (Determine Technological Direction) process and on the COBIT information criteria there is a primary effect on effectiveness and efficiency. The fifth IT goal (Ensure seamless integration of applications into business processes) is associated with the AI4 (Enable Operation and Use) process and on the COBIT information criteria there is a primary in effectiveness and efficiency and secondary on integrity, availability, compliance, and reliability.

The sixth IT goal (Ensure proper use and performance of the application and technology solutions) is associated with the PO6 (Communicate Management Aims and Direction) and AI4 (Enable Operation and Use) process and on the COBIT information criteria there is a primary in effectiveness and efficiency and secondary on integrity, availability, compliance, and reliability. The seventh IT goal (Optimise the IT infrastructure, resources and capabilities) is linked to the PO3 (Determine Technological Direction) process and on the COBIT information criteria there is a primary on effectiveness and efficiency. The eighth IT goal (Ensure that critical and confidential information is withheld from those who should not have access to it) is linked to the PO6 (Communicate Management Aims and Direction) process and on the COBIT information criteria there is a primary in effectiveness and secondary in compliance and so on until the eleventh IT goal. The following is a mapping table of IT goals to IT processes which can be seen in Table 3 . 
Table 3. Linking IT Goals to IT Processes

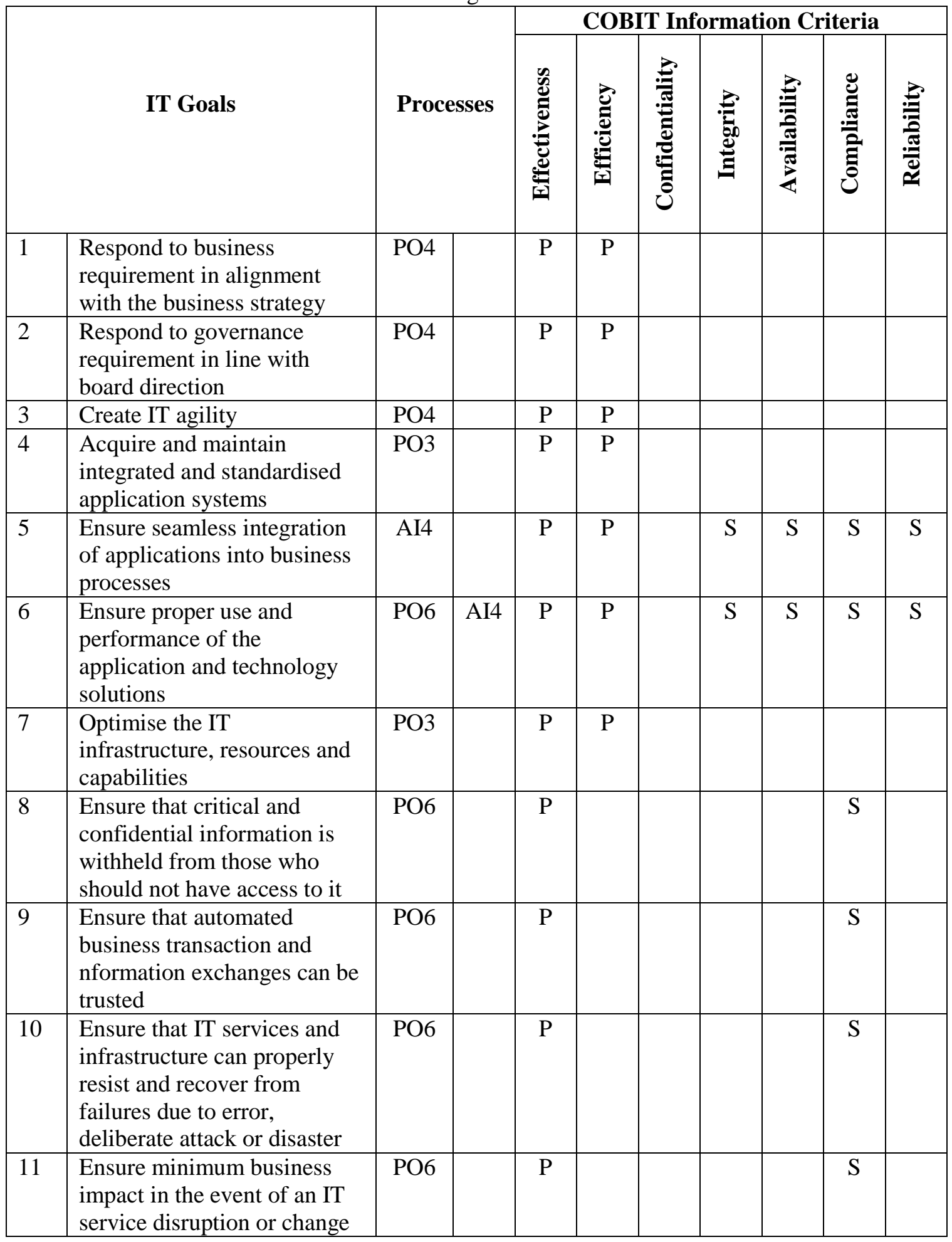

Furthermore, as described earlier the authors connect between business goals and IT goals. Business goals describe what a company expects to accomplish over a specific period of time. Businesses usually outline their goals and objectives in their business plans. Goals may pertain to the company as a whole, departments, employees, customers, or any other area of the business, whereas IT goal is what the company expects for IT running in the company. The 
following is an internal balanced scorecard perspective that is related to the business goals and IT goals that can be seen in table 4 .

Table 4. Linking BSC Internal Perspective to Business Goals and IT Goals

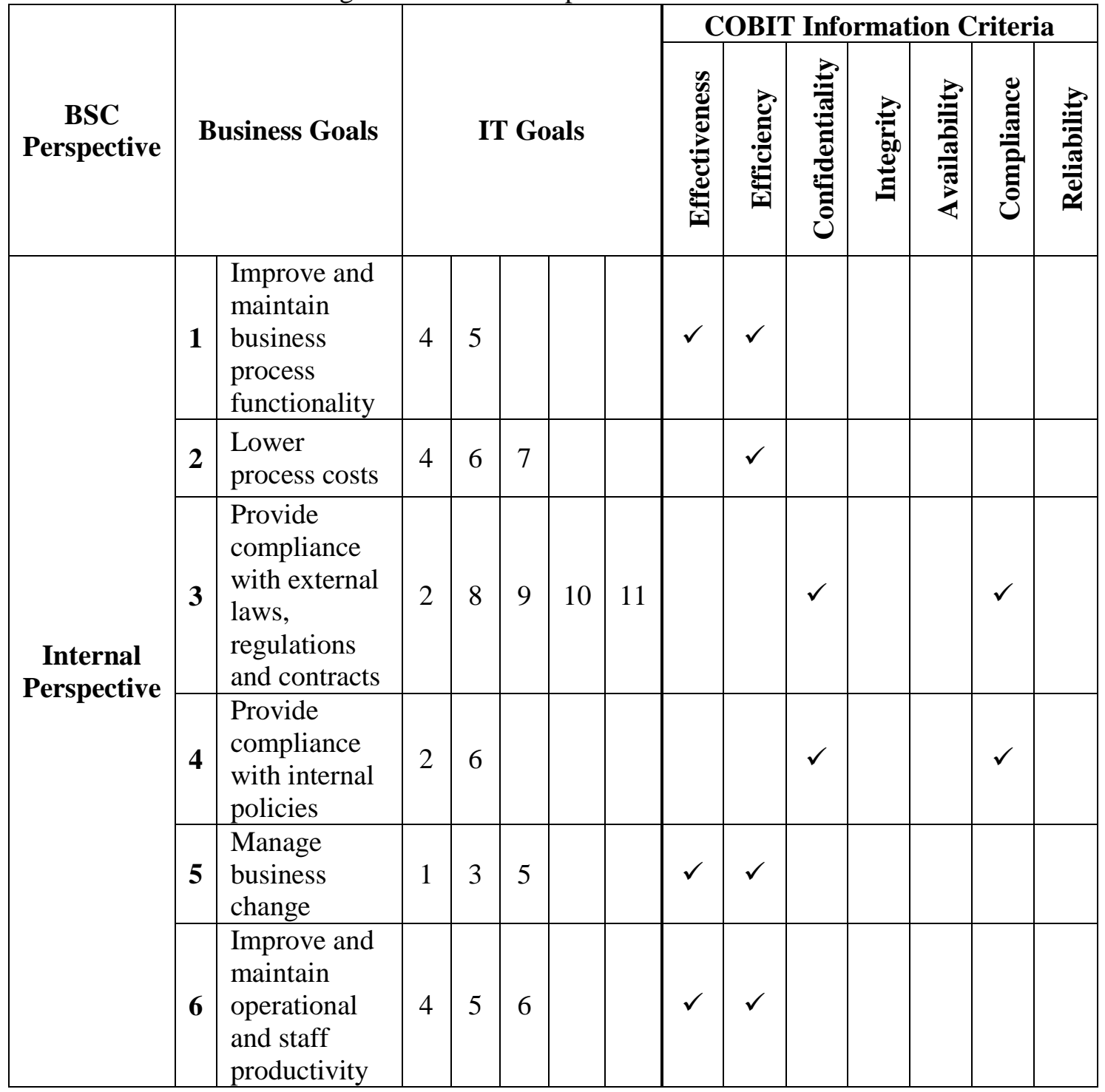

This table maps the business goals, managed according to a balanced scorecard, to the IT goals and COBIT information criteria. This helps indicate a given common business goal, the IT goals that usually support for this goal and the COBIT information criteria that associated to the business goal. The set of 6 business goals should not be assume as a complete set of all probable business goals; it is an option of relevant business goals that can have a clear impact on IT, in which there are BSC perspectives used, business goals, IT goals, and COBIT information criteria consisting of effectiveness, efficiency, confidentiality, integrity, availability, compliance, and reliability.

For the first business goal (Improve and maintain business process functionality) is associated with IT goals number 4 (Acquire and maintain integrated and standardized application systems) and 5 (Ensure seamless integration of applications into business processes) and there is effectiveness and efficiency in the COBIT. The second business goal (Lower process costs) is associated with IT goals number 4 (Acquire and maintain integrated and standardized application systems), 6 (Optimize the IT infrastructure, resources and capabilities) 
and there is efficiency in the COBIT information criteria. The third business goal (Provide compliance with external laws, regulations and contracts) is related to IT goal number 2 (Respond to governance requirement in line with direction board), 8 (Ensure that critical and confidential information is withheld from those who should not have access to it), 10 (Ensure that IT services and infrastructure can properly resist and recover from failures due to error, deliberate attack or disaster), and 11 (Ensure minimum business impact in the event of an IT service disruption or change), and there is confidentiality and compliance on the COBIT information criteria.

The fourth business goal (Provide compliance with internal policies) is related to IT goal number 2 (Respond to governance requirement in line with direction direction) and 6 (Ensure proper use and performance of the application and technology solutions), and there is confidentiality and compliance on COBIT information criteria as in previous business goals. The fifth business goal (Manage business change) is connected with IT goals number 1 (Respond to Business Requirement in alignment with the Business Strategy), 3 (Create IT Agility), and 5 (Ensure Seamless Integration of Applications into Business Process) and Effectiveness and efficiency. The last business goal (Improve and maintain operational and staff productivity) is linked with IT goals number 4 (Acquire and maintain integrated and standardized application systems), and Ensure proper use and performance of the application and technology solutions) and there is also effectiveness and efficiency in the COBIT information criteria as well as the previous business goal.

\section{CONCLUSION}

Based on the result of the research it can be concluded that still many deficiencies in company which can be proved with maturity level which is still below expected level, where can be seen that current maturity level of PO domain at company that is 1 , whereas company expect maturity level 3 and current maturity level on the AI domain is 1, while the company expects at level 2. Therefore, it can be concluded that the company must be harder in trying to reach the expected level because it is still quite far to reach the expected level. From the BSC perspective, the authors use an internal perspective, whereas if the overall domain connected to the internal perspective of BSC averaged the result of 1.16, this is due to the company's deficiencies.

\section{RECOMMENDATION}

The recommendation from the authors for the company that is, on the domain of the company PO is advised to ensure the IT process in the manufacture of sales and inventory programs to fit the existing user requirements. The author recommends to the company to add features on the application is a feature to select the date when the user to do the closing process due to the closing process can be done at the beginning of the next month. Then the company is also advised to periodically review the IT organization in order to meet the expected business objectives. In AI domains, the authors suggest the identification of all technical aspects of the system, the operational aspects of the system, and aspects of system usage so that the company can ensure business processes aligned with the application on the company. These things are recommended by the author for the company to achieve the expected maturity level.

\section{ACKNOWLEDGMENT}

The authors would like to thank the company that we made as the object of research that has provided support to this research. 


\section{REFERENCES}

[1] Anand, A., Wamba, S. F., \& Gnanzou, D. (2013). A Literature Review on Business Process Management, Business Process Reengineering, and Business Process Innovation. Enterprise and Organizational Modeling and Simulation, Eomas 2013, 153, 1-23. https://doi.org/10.1007/978-3-642-41638-5_1.

[2] Abidin, N., \& Samopa, F. (2016). Jurnal Sistem Informasi, 5(5), 612-628.

[3] Andry, J. F. (2016). Audit of IT Governance Based on COBIT 5 Assessments: A Case Study. Jurnal Teknologi Dan Sistem Informasi, 2(2), 27-34. Retrieved from http://teknosi.fti.unand.ac.id/index.php/teknosi/article/view/45/35.

[4] Fadzil, F., Haron, H., \& Jantan, M. (2005). Internal Auditing Practices and Internal Control System. Managerial Auditing Journal, 20(8), 844-866.

[5] Polo, J. O., \& Oima, D. (2013). Effect of Computerised Accounting Systems on Audit Risk Management in Public Enterprises: A Case of Kisumu County, Kenya. International Journal of Education and Research, 1(5), 1-10.

[6] Hanifi, A. L. (2013). Analyzing IT Function Using COBIT 4.1 A Case Study of Malaysian Private University. Journal of Economics, Business and Management, 1(4), 406-408.

[7] Andry, J. F. (2016). Performance Measurement of IT Governance: A Case Study. Jurnal Sistem Informasi, 12(2), 57-63.

[8] Wijayanti, N. Y., Setiawan, W., \& Sukamto, R. A. (2017). Performance Assessment of IT Governance with Balanced ScoreCard and COBIT 4.1 of Universitas Pendidikan Indonesia. Journal of Physics: Conference Series, 1-7.

[9] Krisanthi, G. A. T., Sukarsa, I. M., \& Agung Bayupati, I. P. (2014). Governance audit of application procurement using COBIT framework. Journal of Theoretical and Applied Information Technology, 59(2), 342-351.

[10] IT Governance Institute Team. (2007). COBIT 4.1. USA: IT Governance Institute.

[11] Rehor, P., \& Holatova, D. (2013). Application of Balanced Scorecard Method As a Tool for Strategic Management of Chosen Municipality. International Conference 2013, 333340.

[12] Wisniewski, M., \& Olafsson, S. (2004). Developing balanced scorecards in local authorities: a comparison of experience. International Journal of Productivity and Performance Management, 53(7), 602-610.

[13] Kisner, R. A. (2007). Using the Balanced Scorecard to Achieve Career Success. Government Finance Review, 23(5), 65-68.

[14] Zizlavsky, O. (2014). The balanced scorecard: Innovative performance measurement and management control system. Journal of Technology Management and Innovation, 9(3), 210-222. https://doi.org/10.4067/S0718-27242014000300016

[15] Heryudo, S., Kurniati, A. P., Perdana, E. G., Heryudo, S., Kurniati, A. P., \& Perdana, E. G. (2013). Information Technology Governance Using COBIT 4 . 1 Framework for Supporting Service of Information Technology ( Case Study: PT . Pupuk Sriwidjaja Palembang ). Information Systems International Conference (ISICO), 1-7.

[16] Rubino, M., \& Vitolla, F. (2014). Internal control over financial reporting: opportunities using the COBIT framework. Managerial Auditing Journal (Vol. 29). https://doi.org/10.1108/MAJ-03-2014-1016

[17] Al-Hosaini, F. F., \& Sofian, S. (2015). A Review of Balanced Scorecard Framework in Higher Education Institution (HEIs). International Review of Management and Marketing, 5(1), 26-35.

[18] Andry, J. F. (2016). Audit Tata Kelola TI Menggunakan Kerangka Kerja Cobit Pada Domain DS Dan ME Di Perusahaan KREAVI INFORMATIKA SOLUSINDO. Seminar Nasional Teknologi Informasi Dan Komunikasi 2016 (SENTIKA 2016), 18-19. 
[19] Malgwi, D. A. A., \& H. Dahiru. (2014). Balanced Scorecard financial measurement of organizational performance: A review. IOSR Journal of Economics and Finance, 4(6), 110.

[20] Gekonge, C. O. (2005). What a System! The Professional Journal of KASNEB, (4).

[21] Kairu, Wafula, Okaka, Odera, \& Akerele. (2013). Effects of Balanced Scorecard on Performance of Firms in The Service Sector. European Journal of Business and Management, 5(9). 